\title{
1951 Yılında Yazılmış Bir Mevlid: Ali Bakî’nin Yeni Tulû’ât-ı Mevlûdü’n-Nebî’si
}

\section{A Mawlid Written in 1951: Yeni Tulu'at-ı Mevludü'n-Nebi of Ali Baki}

\author{
Sedat Kardaş a \\ ${ }^{a}$ Dr. Öğr. Üyesi, Muş Alparslan Üniversitesi, Fen Edebiyat Fakültesi, Türk Dili ve Edebiyatı Bölümü, 49250, Muş/Türkiye. \\ ORCID: 0000-0002-3444-0106
}

\section{MAKALE BILGIISI}

\section{Makale Geçmişi:}

Başvuru tarihi: 05 Ocak 2018

Düzeltme tarihi: 07 Şubat 2018

Kabul tarihi: 19 Şubat 2018

\section{Anahtar Kelimeler:}

Ali Bakî

Mevlid

Yeni Tulû'ât-1 Mevlûdü'n-Nebî

\section{ARTICLE INFO}

\section{Article history:}

Received 05 January 2018

Received in revised form 07 February 2018

Accepted 19 February 2018

\section{Keywords:}

Ali Baki

Mawlid

Yeni Tulu'at-1 Mevludü'n-Nebi
ÖZ

Sözlük anlamıyla "doğum, doğum yeri ve doğum vakti” anlamlarına gelen mevlid, terim olarak, İslam peygamberinin doğumunu, doğduğu zaman ve yeri, hayatını, mucizelerini, gazalarını, ahlakını, vefatını vb. yönlerini konu alan eserlere verilen addır. Mevlid türünün en tanınmış ürünü, Süleyman Çelebi tarafından yazılan Vesîletü'n-Necât'tır. Zamanla diğer şairler de bu eseri örnek alıp aynı türde eserler kaleme almıştır. Böylece günümüze kadar süren bir mevlid yazma geleneği meydana gelmiştir. Mevlid türünde yazıldığı bilinen son eser, Ali Bakî (Gül) tarafından 1951 yılında Arap harfleri ve talik yazı stiliyle kaleme alınan Yeni Tulû'ât-1 Mevlûdü'n-Nebî'dir. Bu çalışmada, Ali Bakî'nin biyografisine dair bilgiler verildikten sonra şairin mevlidi tanıtılmış ve eldeki tek nüshadan hareketle transkripsiyonlu metni verilmiştir.

\section{A B S T R ACT}

Mawlid, meaning birth, birthplace and birthtime, as a term is the name given to the works dealing with birth, birthtime, birthplace, life, miracles, holy wars, morals, death and aspects etc. of Islamic prophet. The most well-known piece of mawlid type is Vesiletü'n-Necat written by Süleyman Çelebi. Other poets have also written the same kind of works by taking this work as an example in time. Thus, a mawlid writing tradition has emerged reaching today. The latest work whose existence is known within the written mawlid type works is Yeni Tulu'at-1 Mevludü'n-Nebi, written in Arabic letters and talik writing style in 1951 by Ali Baki (Gül). In this study, above mentioned mawlid of Ali Baki has been introduced and transcriptional text of the work is also presented by means of the single available copy.

\section{Giriş}

Türk edebiyatında, dinî türler içerisinde en yaygın olanların başında mevlid gelmektedir. Arapça bir kelime olan mevlid " $v, l, d$ " kökünden gelip sözlük anlamı olarak "doğma, viladet; bir zatın doğduğu zaman; doğulan yer" (Şemsettin Sami, 2010: 791), "Hz. Muhammed'in doğumunu ve hayatını anlamak için yazılmış manzum eser" (Çağbayır, 2007: 3181), “mev'id vezninde doğurmak" (Mütercim Âsım Efendi, 2013: 141) anlamındadır. Özel isim ve terim olarak da "Íslam Peygamberinin doğumunu anlatmak ve doğumunu kutlamak üzere yazılmış manzum eserlere mevlit adı verilmiştir" (Akkuş, 2007: 156).
Esas itibariyle İslam peygamberinin doğumunu, risaletini, mucizelerini, miraç ve vefatını ele alan mevlidler, edebî bir üslupla ve çoğunlukla mesnevi nazım şekliyle yazılan eserlerdir (Kütük, 2016: 28). Bunun dişında Hz. Ali ve Hz. Fatıma için de mevlidler yazılmıştır. Söz konusu mevlidler Hakan Yekbaş tarafindan kitaplaştırılmıştır (Yekbaş, 2012). Mevlid türü hakkında şimdiye kadar yapılmış en ayrıntılı çalışma özelliği taşıyan Mevlid-nâme (Köksal, 2011) adlı kitabın yazarı olan M. Fatih Köksal, İslam peygamberi dışında Hz. Ali ve Hz. Fatıma hakkında düzenlenen mevlidlerin varlığından hareketle dört halife, on iki imam yahut mezhep imamları gibi diğer din büyükleri için de mevlidler yazılmış olabileceğini, en azından türün buna imkân verdiğini ifade etmiştir (Köksal, 2016: 3).

\footnotetext{
* Sorumlu yazar/Corresponding author.

e-posta: sedat_kardas@hotmail.com
} 
Mevlid türünün bu kadar yaygın olmasının sebebi olarak geniş kitleler tarafından sevilip okunan Süleyman Çelebi'nin Mevlid'i (Vesîletü'n-Necât) gösterilmiştir. Bu eser aynı zamanda türün en başarılı örneği olarak kabul görmektedir. Söz konusu eser Faruk Kadri Timurtaş (Süleyman Çelebi, 1980), Necla Pekolcay (Süleyman Çelebi, 2013), İskender Pala (Süleyman Çelebi, 2014) ve Cemal Kurnaz-Mustafa Tatcı (Hüseyyin Vassaf, 1999) gibi isimler tarafından farklı zamanlarda defalarca yayıma hazırlanmıştır.

İskender-nâme müellifi Ahmedî (öl. 815 / M. 1412-13) tarafından H. 810 / M. 1407'de kaleme alınan mevlid, Türk edebiyatının bilinen ilk mevlidi olarak kabul edilmektedir. Ancak Kadı Darir tarafından Sultân Berkuk'un emriyle yazılmaya başlanıp 790/1380'de tamamlanarak ona takdim edilen Sîretü'n-Nebî adlı eser içerisinde yer alan $\mathrm{Hz}$. Muhammed'in doğumunun anlatıldı̆̆ 55 beyitlik manzume, Türk edebiyatının bilinen ilk mevlid manzumesidir (Kartal 2015). Buna rağmen, yüzyıllar boyu şairler, türün en güzel örneği olarak kabul edilen Süleyman Çelebi (öl. 825 / M. 1422) tarafından H. 812 / M.1409 tarihinde yazılan Vesîletü'n-Necât'1 örnek alıp mevlidler kaleme almış ve böylece bir mevlid yazma geleneği oluşmuştur. Bu gelenek günümüze kadar devam etmiş ve son dönem olarak adlandırılan Cumhuriyet devrinde de mevlidler yazılmıştır.

Son dönem mevlidlerinden biri de Ali Bakî’nin 1951 yılında yazmış olduğu Yeni Tulû'ât-l Mevlûdü'n-Nebî̀ adlı manzumedir.

\section{Ali Bak̂̂’nin Yeni Tulū'āt-1 Mevlūdü'n-Nebī’si}

\subsection{Eserin Müellifi}

1451 yılında yazılan eserin müellifi Ali Bakî Gül'dür. Müellifin mahlası Mevlid metninin yer aldığı manzum Hacı Bektaş-1 Veli Velâyetnâmesi'nin sonunda yer alan "Kâtib-i Hâksâr Alî Bakî'nin Târîh-i Tahrîrine Söyledikleri Târîh" başlıklı manzumede, şaire ait diğer manzumeler ve Mevlid'in 139. beyitinde açıkça söylenmiştir:

\section{‘Alì Bākị el açar ịhsānıña Pādişāhım bağlıyım fermānıña}

Ali Bakî, Pervâne mahlasını da kullanan son devir Bektaşî şairi Sıdkî Baba'nın oğludur. Ali Bakî Gül, 1897 yılında Amasya ilinin Merzifon ilçesine bağlı Harız (Gümüştepe) köyünde doğmuş, 24 Aralık 1956 tarihinde aynı köyde vefat etmiştir (Günaydın, 2008: 156).

Ali Bakî, Harız köyünde imamlık yapmıştır. İmamlık dışında askerde öğrendiği terzilik ve marangozluk işleriyle de meşgul olmuştur. Hatta II. Dünya Savaşı yıllarında halka sivil savunma kursları vermiştir. Yaşlılık döneminde terzilik ve marangozluğu bırakmış, kalan ömrünü okuyup yazmakla geçirmiştir. Son şiiri 2 Aralık 1956 tarihlidir (Günaydın, 2008: 158-159).

Şairin, babası ve kardeşi gibi şiirlerini topladığı bir Divan'1 mevcuttur. Söz konusu eser, Baki Yaşa Altınok tarafindan yayımlanmıştır (Altınok, 2017).

\subsection{Eserin Ad1}

Mevlid yazarlarının kimi zaman eserlerine hususi isimler verdikleri bilinmektedir. Çalışmaya konu olan eserin müellifi Ali Bakî de manzumesine başlık atmış ve eserin adını “'Yeni Tulū'āt-ı Mevlūdü'n-Nebî̀' olarak koymuştur.

\subsection{Eserin Yazılış Tarihi}

Mevlid metninin yer aldığı manzum Hacı Bektaş-1 Veli Velâyetnâmesi'nin sonunda ve Mevlid bölümününden hemen önce 160b-161a numaralı varağında yer alan "Kâtibi Hâksâr Alî Bakî'nin Târîh-i Tahrîrine Söyledikleri Târîh" başlıklı manzumenin sondan ikinci beytinde şair, eserin yazılış tarihini tarih düşürme yoluyla vermiştir:

Ve bir hem dil-i zārı̃̃ tārīh-i tahrīridir Himmetine taleb-kārım meded her ān el-amān

$\mathrm{Bu}$ beyitteki harflerin ebced karşılığı 1951 yılını vermektedir.

\subsection{Eserin Vezni}

Ali Bakî’nin mevlid manzumesi, temel olarak, Süleyman Çelebi ile birlikte Mevlid vezni haline gelen remel bahrinin fâ'ilâtün / fâ'ilâtün / fâ'ilâtün kalıbı ile yazılmıştır. Ayrı bölüm özelliği taşıyan kısımların sonunda tekrar eden nakarat beyti olan aşağıdaki beyitte bu vezin kullanılmıştır. Ancak mevlidlerde tesadüf edilen çift vezin kullanılışı, son dönemlerde yazılan bu mevlidde de görülmektedir. Yine çift vezin kullanılan diğer mevlidlerde olduğu gibi bu mevlidde de hece sayıları aynı olan fâ'ilâtün / fâ'ilâtün / fâ'ilün ve mefâ'îlün / mefâ'̂̀lün / fe'ûlün kalıpları birlikte kullanılmıştır. Vezin geçişlerinde ise istikrar yoktur. Bunun yanında Mevlidin başında dörtlükler şeklinde yazılan manzumelerde kullanılan belirli bir vezin yoktur. Bu durum söz konusu bölümün hece vezni ile yazıldığını düşündürmektedir. Nitekim söz konusu manzumelerin bütün dörtlüklerinde hece sayısı 11 'dir.

Şairin eserinde vezni başarılı bir şekilde kullandığını söylemek oldukça güçtür. Vezin kusurları oldukça fazladır. Öyle ki bazı beyitlerin veznini tespit etmek oldukça zor hale gelmektedir. Yukarıda verilen nakarat beytinin ilk misraı ve mahlasının geçtiği şu beyit şairin aruz veznini kullanmadaki başarısızlığı hakkında bize yeterli fikir vermektedir:

\section{‘Alì Bākì el açar ihsānı̃̃a Pādişāhım bag̀lıyım fermānıña}

Şair hem nakarat beytinde hem de yukarıdaki beytin ilk misraına fầilâtün tefilesi ile başlaması gerekirken, ilk tefileler mefâ'îlün'e tekabül etmektedir. Beyti vezne uydurmak için şair isminde bir imale ve zihaf yapmak gerekmektedir. Eserin tamamında da zihaf ve imaleler oldukça fazla yekûn tutmaktadır.

\subsection{Eserin Beyit Sayıs1}

Ali Bakî beyit sayısını eser içerisinde belirtmemiștir. Elimizdeki nüshaya göre Yeni Tulū'āt-1 Mevlūdü'n-Nebī toplam 141 beyitten oluşmaktadır. Bununla birlikte mevlidin başında biri 5 diğeri 4 dörtlükten oluşan iki adet murabba vardır. Yine 71 ve 72 . beyitler arasında teşrik tekbiri mevcuttur.

\subsection{Eserin Muhtevas1}

İslam peygamberinin doğumu, yaşamı ve güzel ahlakından kesitlerin konu edindiği eserde bölüm başlıkları 
bulunmamaktadır. Daha doğrusu bölümler birbirinden kesin çizgilerle ayrılmamaktadır. Bölümler birbirinden genel olarak eser boyunca tekrar eden vasita beytiyle ayrilsa da bunda da bir istikrar yoktur. Mevlid'in başında yer alan dörtlükle yazılmış olan ilk manzume esere giriș mahiyeti taşırken ikinci manzume bir münacattır. Eserin muhtevası hakkında fikir edinmemizi sağlayan diğer bölümlerinin edebî türü ve tarzları şu şekilde gösterilebilir:

1-19. beyitler: Mevize tarzında giriş

20-40. beyitler: Naat

25-39. beyitler: Âlemin yaratılışı ve Hz. Adem'den Hz. Muhammed'e, ondan da Hz. Ali'ye kadar bir nübüvvet ve soy silsilesi

\section{5-43. beytiler: Hz. Muhammed'in ailesi}

41-82. beyitler: Hz. Muhammedin doğuşu

84-103. beyitler: Asıl konunun işlendiği bölüm

105-128. beyitler: Medhiye tarzında $\mathrm{Hz}$. Muhammed'in çocukluğu

\section{0-128. beyitler: Mucizat}

129-140. beyitler: Münacat ve dua

136-140. beyitler: Tevbename

$\mathrm{Bu}$ bölümler dişında eserin 141. beytinden sonra “ $D u$ ' $\bar{a}-y 1$ Mevlūd' başlıklı bölümde mevlide ait dua metni verilmiştir. Arapça ve Türkçe mensur olarak yazılan bu bölüm, diğer mevlid neşirlerindeki genel uygulamaya uyularak metnine dâhil edilmemiştir.

\subsection{Eserin Süleyman Çelebi'nin Eseriyle Karşılaştırılması}

Mevlid türü deyince akla gelen ilk isim Süleyman Çelebi ve onun Vesîletü'n-Necât adlı eseridir. Miladi 1409 yılında yazılan Vesîletü'n-Necât toplum tarafindan çok beğenilmiş ve eserin çeşitli zamanlarda okunması ile birlikte mevlid okumak bir gelenek haline gelmiştir. Şairler de bu eseri örnek alıp mevlidler kaleme almıştır. Böylece bir mevlid yazma geleneği teşekkül etmiştir. Bu gelenek günümüze kadar devam etmektedir. Vesîletü 'n-Necât'tan 542 y1l sonra kaleme alınan ve varlığ yazılan eser olan 1951 tarihli Yeni Tulû'ât-ı Mevlûdü'n-Neb̂̀ de bu geleneğin bir ürünü olarak kaleme alınmıştır. Hiç şüphesiz Ali Bakî de diğer müellifler gibi eserini yazarken Süleyman Çelebi'nin mevlidinden etkilenmiştir. Eser başta vezin olmak üzere, vasıta beyitlerinin varlığ Süleyman Çelebi'nin eserini andırmaktadır.

Her şeyden evvel iki mevlid de manzum olarak mesnevi nazım şekli ve aruz vezninin remel bahrinin fâ'ilâtün / fâ'ilâtün / fâ'ilün kalıbıyla yazılmıştır. Ancak Ali Bakî bu vezin yanında mefâ'îlün / mefâ'̂̀lün / fe'ûlün kalıbını da kullanmıştır. İki metinde de imale ve zihaflar görülürken, doğal olarak Süleyman Çelebi Ali Bakî'ye nazaran vezni uygulamada daha başarılıdır.

Vesîletü'n-Necât hacim olarak yaklaşık olarak 800 beyitten oluşurken, Yeni Tulû'ât-l Mevlûdü'n-Nebî sadece 141 beyitten meydana gelmiştir. Bunun bir sonucu olarak Ali Bakî'nin manzumesi, Süleyman Çelebi'nin mevlidine göre konuyu işlemede ayrıntılara inmemiş ve yüzeysel kalmıştır.
Mevlid türünün özelliklerinden biri de eser boyunca tekrarlanan ve çoğunlukla peygambere salât ü selâm getirilmesi istenen beyitlerin varlığıdır. Vasıta beyti olarak adlandırılan bu bölüm Süleyman Çelebi mevlidinde şu şekildedir:

\section{Ger dilerseniz bulasız oddan necât Işk ile derd ile aydun es-salât}

Ali Bakî'nin mevlidinde de vasıta beyti bu beyitle paralellik gösterir:

Dilerseñ nār-1 cehennemden necāt Söyle her dem caşkile gel eș-ṣalāt

Görüldüğü gibi vasıta beyitleri hemen hemen aynıdır. Bunun dışındaki benzerlikler çoğunlukla mevlid türünün genel özelliklerinden kaynaklanmaktadır. Belirli bir konu olunca mevlidlerde kullanılan kelimelerin benzerlik göstermesi de kaçınılmazdır. Mevlidler arasındaki ifade benzerlikleri bu bağlamda değerlendirilmelidir.

\subsection{Eserin Dil ve Anlatım Özellikleri}

Latin harflerine geçişten 23 y1l sonra, 1951 gibi geç bir tarihte Arap harfleri ve talik yazı stiliyle el yazması olarak kaleme alınan eserin dili, 1951'in dilinden çok klasik dönem eserlerinin dil özelliklerini taşımaktadır. Kuşkusuz bunda diğer mevlid şairleri gibi Ali Bakî'nin Süleyman Çelebi’ye özenip onun eserinden etkilenmesi etkili olmuştur. Eserde yer yer görülen Eski Anadolu Türkçesinin dil özellikleri bu durumla açıklanabilir. Bu döneme ait istek kipi -gll/-gil eki ve "okşamak, sıvazlamak" anlamındaki sıgamak fiilinin kullanımı bu duruma örnek olarak verilebilir.

Mevlid türünde de diğer dinî türler gibi amaç geniş kitlelere hitap etmek olduğundan sade bir dil tercih edilir. Bunun yanında şairler medhiye yaparken Arapça kelimelere sık olarak başvururlar. Bu durum Ali Bakî'nin eserinde de mevcuttur.

\subsection{Eserin Nüshas}

Ali Bakî'ye ait Yeni Tulû'ât-ı Mevlûdü'n-Nebî adlı eserin tek nüshası Ankara Milli Kütüphane'de 06 Mil Yz A 5300 numarada kayıtlıdır. Mevlid metni aynı numarada kayıtlı, Ali Bakî tarafından istinsah edilen Ali Nihanî'ye ait manzum Hacı Bektaş-ı Velî Velayetnamesi adlı eserin sonunda yer almaktadır. Mevlid metninden hemen önce yer alan "Kâtib-i Hâk-sâr Alî Bakî'nin Târih-i Tahrîrine Söylediği Târih" başlıklı manzumeden, eserin 1951 yılında istinsah edildiği anlaşılmaktadır.

Müstensih Ali Bâki, söz konusu eserde bazen bölüm sonlarında kendi manzumelerine yer vermiştir. Bu şekilde metin içinde altı manzume ve metnin sonunda bir mevlid ile ilticaname başlıklı bir şiir yazmıştır. Ayrıca nüshanın sonunda "Evsâf-ı Ahmed Cemâleddin ve Halife-i Manevisi Sıdkî Baba ve Nâzım-ı Kitâb Ali Nihânî Efendi" başlıklı bölümde, Sıdkî Baba'nın hayat hikâyesine ve Şeyh Feyzullah Efendi ile oğulları Ahmed Cemalleddin ve Veliyüddin ile olan ilişkilerine değindikten sonra müellif Ali Nihanî hakkında bilgiler verilmiştir. Söz konusu nüshanın özellikleri Tablo 1'deki şekilde gösterilebilir. 
Tablo 1. Yeni Tulû'ât-1 Mevlûdü'n-Nebî Adlı Eserin Nüshasına İlişkin Özellikler

\begin{tabular}{ll}
\hline Kriter & Açıklama \\
\hline M3 & Milli Kütüphane 06 Mil Yz A 5300 \\
Eser Adı & Velâyet-nâme-i Hâcı Bektâş \\
Yazar Adı & Hâcı Bektâş-1 Velî Horâsânî \\
Müstensih & Ali Bakî \\
İstinsah Tarihi & 1951 \\
Boyut & 230 x 147-190 x 110 mm. \\
Yaprak & 166 \\
Satır & 21 (Çift Sütun) \\
Yazı & Talik \\
Kâğıt & Harf filigranlı \\
Cilt & Şemseli, zencirekli, kahverengi meşin bir \\
& cilt içerisindedir. \\
Başı & Gel ey dil söyle ism-i Hakk'ı akdem \\
& Ki ismi cümle esmâya mukaddem \\
Son & Nihânî hatmine târîh dilerseñ \\
& Dile ikdâm-1 Feyzu'llâh Efendi \\
\hline
\end{tabular}

Talik yazısı ile kaleme alınan nüshada, başlık siyah renkle yazılmışken vasıta beyitleri ve şairin mahlası kırmızı mürekkeple yazılmıştır.

\section{Sonuç}

Halk ozanı Sıdkî Baba'nın oğlu Ali Bakî (Gül) tarafından 1951 yılında Arap harfleriyle kaleme alınan ve Türk edebiyatında mevlid türünün varlığı bilinen en son örneği olan Yeni Tulû'ât-ı Mevlûdü'n-Nebî adlı manzume, başta mevlid geleneğinin devam ettirilmesi olmak üzere, klasik edebiyat anlayışının Cumhuriyet döneminde de sürdürüldüğünü göstermesi açısından önemli bir eserdir.

Elimizde tek nüshası olan ve 141 beyitten meydana gelen mevlid metni, türünn diğer örneklerinde olduğu gibi, geleneğin belirleyicisi durumundaki Süleyman Çelebi'nin Vesîletü'n-Necât'ından izler taşımaktadır.

Sade ve anlaşılır bir dil kullanarak eserini kaleme alan Ali Bakî, 20. yüzyıl dil özelliklerinden çok klasik dönem eserlerinin dil özelliklerine başvurmuştur. Latin Alfabesine geçtikten 23 yıl sonra, 1951 gibi geç bir tarihte, şairin Klasik edebiyatın nazım şekli olan mesnevi nazım şekli ve aruz vezni ile mevlid kaleme alıp geleneği sürdürme çabası dikkat çekici bir özelliktir. Ancak Ali Bakî'nin, nazım tekniği bakımından başarı gösterdiğini söylemek zordur. Klasik edebiyatta aynı zamanda ahenk unsuru olan aruzu uygularken sıkça başvurduğu imale ve zihaflar, metindeki kafiye kusurları, kelime tekrarları eserin edebi değerini zayıflatan unsurlardır.

Sonuç olarak, bahsi geçen manzumenin, kusurlarına rağmen mevlid yazma geleneğini sürdürmesi ve varlığ mevlid metni olması sebebiyle önem arz ettiği söylenebilir. $\mathrm{Bu}$ açıdan bakıldığında söz konusu eser üzerine yapılan bu çalışmanın alana katkı sağlayacağı düşünülmektedir.

\section{Notlar:}

1. Transkripsiyonlu Metnin Hazırlanmasında Takip Edilen Esaslar

(i) Metin oluşturulurken Türkiye'de kullanımı yaygın olan transkripsiyon sistemi kullanıldı.

(ii) Beyit numaraları, sayfa numaraları ve varak numaraları metnin solunda beyitlerden önce koyu renkle gösterildi. 161b (221) gibi. Burada 161b varak numarasını, (221) gibi parantez içindeki rakamlar yazma eserdeki kayıtlı sayfa numaralarını göstermektedir.

(iii) Vasita beyitleri italik olarak verildi.

(iv) Metne yapılan müdahaleler [...] şeklinde gösterildi.

(v) Vezin geçişleri düzensiz ve vezin kusurları fazla olduğu için tek tek aparatta gösterilmedi.

(vi) İmla ile ilgili hususlarda temel olarak İsmail Ünver'in "Çevriyazıda Yazım Birliği Üzerine Öneriler" adlı makalesinde ortaya konan ilkelere uyulmuş, metin transkribe edilirken eserin yazıldığı tarih dikkate alınarak günümüz imlasına göre okunmuştur. Metinde vokal uyumu dikkate alınmış, ünsüzlerde ise müellifin tercihlerine bağlı kalınmış ve ünsüz uyumu göz önünde bulundurulmamıştır.

2. Ali Bakî, Yeni Tulû'ât-1 Mevlûdü'n-Nebî'sine isim verirken mevlid kelimesinin halk arasındaki kullanımını göz önünde bulundurarak, mevlüd şeklini kullanmıştır. Bu çalışmada da şairin bu tercihine bağlı kalınmıştır.

\section{Kaynakça}

Akkuş, M. (2007). Klasik Türk Şiirinin Anlam Dünyası Edebi Türler ve Tarzlar. Erzurum: Fenomen Yayınları.

Altınok, B. Y. (2017). Sıdkî Baba'nın Oğlu Ali Bâkî Gül Baba Dîvânı. İstanbul: Helke Yayıncılık.

Çağbayır, Y. (2007). Ötüken Türkçe Sözlük. İstanbul: Ötüken Neşriyat.

Gül, A. B. (1951). Velâyet-nâme-i Hâcı Bektâş. Milli Kütüphane 06 Mil Yz A 5300.

Günaydın, Y. T. (2008). Amasyalı Bir Bektaşî Şairi Ali Bakî Gül. Türk Kültürü ve Hacı Bektaş Veli Dergisi, 45, 155164.

Hüseyin Vassâf (1999). Mevlid, Süleyman Çelebi ve Vesiletü'n-Necât'ı. (Haz. Cemâl Kurnaz-Mustafa Tatc1). Ankara: Akçă̆ Yayınları.

Kartal, A. (2015). Kadı Darîr, Darîr, Gözsüz, Mustafâ bin Yûsuf bin Ömerü'l-Mevlevî el-Erzene'r-Rûmî. Türk Edebiyatı İsimler Sözlüğü. (Erişim: 20.02.2018), http://www.turkedebiyatiisimlersozlugu.com/index.php? sayfa $=$ detay $\&$ detay $=6548$

Köksal, M. F. (2011). Mevlid-nâme. Ankara: TDV Yayınları.

Köksal, M. F. (2016). Türünün İlginç ve Aykırı Bir Örneği: Şeyh Ahmed Hüsâmeddin Mevlidi. CÜ Sosyal Bilimler Dergisi, 40(1), 1-26.

Kütük, R. (2016). Fetih Öncesinde Yazılmış Bir Mevlid: Ayasofya Müezzini Kemâl'in Mevlidü'n-Nebî'si. C $\ddot{U}$ Sosyal Bilimler Dergisi, 40(1), 27-95.

Mütercim Âsım Efendi (2013). el-Okyânûsu'l-Basît fî Tercemeti'l-Kâmûsi'l-Muhît, Kâmûsu'l-Muhît Tercümesi. (Haz.: Mustafa Koç ve Eyyüp Tanrıverdi), 2(1), İstanbul: Türkiye Yazma Eserler Kurumu Başkanlığı Yayınları.

Süleyman Çelebi (1980). Mevlid. (Haz. Faruk K. Timurtaş). İstanbul: Kültür Bakanlığı Yayınları.

Süleyman Çelebi (2013). Mevlid. (Haz. Neclâ Pekolcay). İstanbul: Dergâh Yayınlar1. 
Süleyman Çelebi (2014). Mevlid. (Haz. İskender Pala). İstanbul: Kap1 Yayınları.

Şemsettin Sami (2010). Kamus-ı Türkî. (Haz. Paşa Yavuzarslan). Ankara: TDK Yayınları.

Ünver, İ. (1993). Çevriyazıda Yazım Birliği Üzerine Öneriler. AÜDTCF Türkoloji Dergisi, 11(1), 51-89.

Yekbaş, H. (2012). Türk Edebiyatında Hz. Ali ve Hz. Fâtıma Mevlidleri. Ankara: Asitan Kitap.

\section{Ekler}

\section{Ek 1. Metin: Yeni Tulū'āt-I Mevlūdü'n-Nebī}

161b 1. Olmak isterseñ cihānda ber-murād

(221) Diñle gel bu mevlid-i peyġamberi Olam derseñ Mısr-1 dü cālemde dilşād

Diñle gel bu mevlid-i peyġamberi

2. Gāfil olma ey Muhammed ümmeti Kıyāmetde bulam derseñ raḥmeti İster iseñ ol Nebí'den şefḳati Diñle gel bu mevlid-i peygamberi

3. Nefsiñi katl edip kāmil insān ol Ejdehāā-yı nefs-i şūmdan āsān ol Hem dahı nā’il-i luṭf u ị̣sān ol Diñle gel bu mevlid-i peyġamberi

4. Ol resūl-i Ekreme ḳıl iḳtidā

Bāb-1 eltāâ pākinde ol gedā Dü cihānda mag̉firet kılsın Hudā Diñle gel bu mevlid-i peygamberi

5. Kurulunca yarın ol ulu mahşer Şefí‘'mizdir bizim hayrü'l-beşer Ḳıyāmetde içmek isterseñ kevšer Diñle gel bu mevlid-i peygamberi

$$
* * *
$$

1. Kil bizi lutfuña mazhar yā ilāh ‘Ālemī yoḳdan var eden pādişāh Kamu mücrim el açmış iḥānıña Sen olduñ çūn cāṣi ḳullara penāh

2. Gafūrsuñ ey Huālike-i kevn ü mekān Maġfiret kıl çünkü olduk pür-günāh Emr-i Kün'den var eylediñ cihānı Devr eder emriñle her dem mihr ü māh

3. Cümle eşyā fānīdir sen bākịisiñ

Kadīm ü lā-yezelsiñ bī-iştibāh Dalāletde koyma yā Rabb bizleri Kullarıñ hāline olduñ sen āgāh

4. Gidemedik bașdı gaflet hak yola Açdıñ amma bize nice tọgru rāh Boyun eğmiş dergāhıña ins [ü] cān Bekliyor bābiñda nice rū-siyāh

Dilerseñ nār-1 cehennemden necāt Söyle her dem caşkile gel eș-șalāt $* * *$

Vezin: Fā'ilātün / Fā'ilātün / Fā'ilātün

Mefāōiün / Mefā'îuün / Fe'ūlün
1. Başlayalım gel söze Allāh deyip Her işiñ başında Bismillāh deyip

2. Allāh adın ḳoyma dilden bir vaḳit Șıdḳ ile Allāh deyip yaşlar aḳıt

3. Gaflet uyḳusundan açıp gözleri Allāh’a baġlayalım gel özleri

4. Allāh adı olsa kalbiñde evrād Dü cihānda eder ol seni dilşād

5. Kullarıñ her hāâline eyler nazar Emrini tut sen de kıl Hakdan hazer

6. Hayra dā’ir bir ‘amel ḳıl iktisāb Luṭf-1 Ḥaḳka nā’il ol yevmü'l-ḥisāb

7. Seni yoḳdan var eyledi Kirdgār Sen de çalış ḳullug̉a leyl ü nehār

8. Nefsiñi öldür mücāhidler gibi Ol riyāżet ehli zāhidler gibi

9. O bed-hūylarından eyle ferāgat Allāh içün eyle her dem cibādet

10. Hak emr etdi bize beş vakit namāz Namāz içre Tanrıya eyle niyāz

11. Namāz eyler kulu Allāha vāṣı Namāz ile olur her maḳṣud ḩāṣıl

12. Namāz añla mü’miniñ micrācıdır Namāz cümle dertleriñ cilācıdır

13. Namāz ḳamu günāhları mạ̣v eder Namāz kılan kulu Allāh cafv eder

14. Enbiyālar evliyālar ḳıldılar Ol sebebden Hakka vāṣl oldular

15. Tevhid ile zikr-i Hakka ḳā’im ol Gece gündüz cibādetde dā’im ol

16. ̇̉bādetle kul Allāha yol bulur 'İbādet eyleyen 'abd-i hāas olur

17. Eyler iseñ emr-i Haḳka iḳtidā $\bar{A} b-u$ Kevserden içersiñ ibtidā

18. Ṭutmaz ol kim emr-i Haḳkı gāfilūn Cehennem ehlinden olur kāfirūn

19. Yeter ey dil söyle nedir bu makșūd Hidāyet eylerse vācibü'l-vücūd

20. Nūr-1 Muhammedden eyle gel beyān Anıñ dīiārına müştāḳ ins ü cān

21. Dilerseñ nār-1 cehennemden necāt Söyle her dem raşkile gel eș-șalāt 22. Diñle cāndan mevlid-i peyġamberi İçesiñ 'uḳbāda āb-u Kevsseri 
23. Muțic ol emrine görme dalālet Şefīi olsun saña ol kān-1 raḥmet

24. Hürmetine halk olundu dü cihān Olmasaydı olmaz idi āsumān

25. İbtidā var oldu nūr-1 nübüvvet Șoñra yaradıldı ervāḥ-ı ümmet

26. Luṭ ihsān edip hażret-i Macbūd Melekler buldular hiç yoḳdan vücūd

27. Emr olup yazıldı ber-levh-i kalem Kün dedi var oldu fi'l-cümle cālem

28. On sekiz biñ cāleme verdi düzen Ay u günle ḳıldı dünyāyı rūşen

29. Çār canāṣırdan yaratdı Ādemi Nesl-i Ādemle țoldurdu cālemi

30. Muhammed nūrunu hażret-i Yezdān

Ādemin alnında eyledi cāyān

31. Çünkü nūr-1 Ādemle olunca iẓhār Nice yillar oldu anda ber-ḳarār

32. Ādemden Havvāya nūr naḳl eyledi Ḥażret-i Ḥaḳ gör ol nūru neyledi

33. Ādemin șulbundan geldi Şit Nebi Anda 'ayān oldu çūn sırr-1 ebi

34. Sulbden șulbe etdi ol nūr müntakīil Edeyim oldukç̧a vüscatım naḳil

35. Eyleyince çünkü ‘Abdullāh zuhūr Hikmet-i Hak anda iki oldu nūr

36. Biri 'Abdullāhda eyledi ḳarār Biri oldu Ebū Ṭālibde iẓhār

37. Geldi `Abdullāhdan çünkü Muhammed 'Āleme oldu şefíc nūr-1 Ahad

38. Ebū Țālibden ol nūr-1 velāyet Murtażā dāmād-1 şāh-1 risālet

39. Naḳl etdi nūr-ı Muștafāa evlādına Salavāt ver Muhammediñ adına

40. Dilerseñ nār-1 cehennemden necāt Söyle her dem aş̧kile gel eș-ṣalāt

41. Eminedir Muhammedin anası Şem`a-i nūr-1 Hudā pervānesi

42. 'Abdullāhdır babası nesl-i Halīil Andan zāhir oldu ol nūr-1 Celīl

43. Emineniñ hamli erdi kemāle Put-perestleriñ karīib oldu zevāle

44. On ikisi idi rebīü'l-evvel 'Alāmetler zāhir oldu mükemmel
45. Pazar ertesi gecesi idi ol Dünyāya geldiği dem çünkü resūl

46. Kacbede eylerdi Emīne tavāf Diñle cāndan yoḳ bu sözde hịç hilāf

47. Sacādet-hānede peydā oldu nūr 'Arş-1 a'lāya ḳadar nūr berḳ urur

48. Emīne der indi gökden melekler Zikr-i tevhid ile toldu felekler

49. Bag̉layıp șaf cümlesi de turdular Sacādet-ḥāneye selām verdiler

50. Divār iki şāḳ oldu gör zuhūru Nāgehān çıḳdı oradan üç hūūī

51. Oṭurdular yanımda bā-uṣūli Müjde edip birbirine Resūlü

52. Dediler baña o dem bu kelāmı Dog̉rusundan kā’inātı̃̃ imāmı

53. Haḳḳñ sevgili ḥabỉbi bu og̉lan Anıñ nūru ile tọlar dü cihān

54. Budur enbiyānıñ başında tacı Bu og̉landır cümle derdiñ cilācı

55. On sekiz biñ cāleme sultān budur ‘̇̉m-i ledün ma`nā-yı Ḳur'ān budur

56. Hūrīiler vaṣfını böyle söyledi Emine hatunu āgāh eyledi

57. Gelmesi yaḳlaşdı ol Hayrü’l-beşer Annesine ḳatı ḥarāret düşer

58. Can gözüñ aç gör Haḳkıı̃ bu hikmeti Șundular ḳudretden aña şerbeti

59. Geldi cennetden o şerbet çok lezīz Yoḳ idi mānendi dünyāda hergiz

60. İçdi anı nūra garḳ oldu hemān Buldu andan cümle derdine dermān

61. Ḳyām eyledi Muḥammed ümmeti Bulasıñ her dü cihānda rạ̣meti

62. İçince şerbeti hikmet-i Hudā Bir ḳuş oldu hemān yanımda peydā

63. Ṣıg̉adı arḳamı ol ḳuş bỉ-ḩaber Zāhir olmuş gördüm ol Hayrü'l-beşer

64. Gelince dünyāya ol dem şāh-1 dīn Nūrlara gark oldu hem carş u zemīn

65. Hạk tecālā açdı sekiz cenneti Sākin oldu hem ol nārıñ şiddeti 66. Șallū calā seyyidinā Muhammed Şefḳatine nā̄il eyle yā Aḥad 
67. Dilerseñ nār-1 cehennemden necāt Söyle her dem caşkile gel eș-ṣalāt

68. Yaratdı nūrundan ol peyġamberi

Gözlere tūtiyā ol hāa-1 deri

69. Hakỉkate kadem bas at mecāzı

Edip yaradana ḥamd ü niyāzı

70. Țopla evrākını şöyle tedbī et

Ol resūlüñ caşḳıyla bir tekbīr et

\section{Allāhu ekber Allāhu ekber lā ilāhe ilāllāhu \\ Allāhu ekber \\ Allāhu ekber ve lillāhi'l-hamd}

71. On sekiz biñ cālem handān oldular

Yaradana ḥamd [ü] şükür ḳıldılar

72. İns [ü] cin cümle melek ḳıldı nidā

Dediler kim geldi ol nūr-ı Hudā

73. Gelince dünyāya ol şāh-1 cihān

Nūra gark oldu zemīn ü āsumān

74. Her țarafdan geldi hoş âmed sesi

Dediler hep budur dünyānıñ ıssı

75. Yā Muhammed Muștafāa geldiñ cayān

Sen olduñ ümmetiñ derdine dermān

76. Eyle cāṣīi ümmetiñe şefā'at

Nā’il et luṭfuña ey kān-ı raḥmet

77. Günāhkār ümmetiñ bekler her zamān

Der-i elțāfıñda derler el-āmān

78. Ḳıāmetde sancaġıña al bizi

Cömerdsiñ dergāhına ṭutduk yüzü

79. Senin için yaradıldı kācināt

Nuțuñ ile buldu mürdeler hayayāt

80. Seniñ șānıñdadır levlāke levlāk

Gelmeseydiñ olmaz idi bu eflāk

81. Cümle enbiyānıñ olduñ ser-tācı

Saña ỉmān eden gürūh-ı nācì

82. Seniñ için geldi cālem zuhūra

Seniñ şānıñdadır yüz on dört sūre

83. Dilerseñ nār-1 cehennemden necāt

Söyle her dem caşkile gel eș-ṣalāt

84. Gelince dünyāya ol nūr-1 Hudā

İns ü melek ḳıldı aña iḳtidā

85. Çünkü başdan başa bu fānī dünyā

Cemāl-i pākinden oldu pür-żiyā

86. Birbirine tebşīr etdi melekler Toldu tevhīd sadāsıyla felekler
87. Bu șadādan oldu bỉ-hūş Emīne 'Aḳlı gidip başın eğdi zemine

88. Topladı caklını kendine gelip Tahayyür eyledi bu ḥāli görüp

89. Hūrī melek tolmuş idi otaǵ Alıp ohşarlar idi çün ḳundag̀ı

90. Gördü çekilmiş melekler hūūiler Kimse yoḳ hiç tenhā ḳalmış o yerler

91. Görmedi og̉lunu baḳdı ol yerde Kalbi maḥūn olup düşdü bir derde

92. Tahayyür baḥrine țaldı bir zamān Bu sırrı kalbinde eyledi nihān

93. Eyler iken çün Emīne tefekkür Gördü og̉lun eyledi çoḳ teşekkür

94. Baḳdı bir köşede țurur ol Aḥmed Secdeye ḳapanmış hem nūr-1 Ahad

95. Turmuş Beytullāha ḳarşı ol imām Başı secdede dili söyler kelām

96. Emine ḳıldı bu hāle tacaccüb Diñledi ogglunuñ yanına varıp

97. Der idi yā Huāliḳ-i kevn ü mekān Āşikārdır eşyā yoḳ saña nihān

98. Bu oldu Allāha çün ilk șohbeti Dedi kim vā ümmeti vā ümmeti

99. Der İlāhỉ ilticām budur saña Günāhkār ümmeti vergil baña

100. 'Āciz ümmeti baña bag̀ışla Cömerdseñ şānıña düşeni işle

101. Rahỉmiñ raḥmetiñ çoḳdur yā Ġani Kıyāmetde ḥacīl düşürme beni

102. Ümmetiñ derdine sen ḳıl çāre Etme mahş̧er günü yüzlerin ḳara

103. Rāh-1 müstaḳime eyle hidāyet Șırāṭ köprüsünden geçir selāmet

104. Anları hıfz ile her dem yā Ahad Şiddet-i nār-1 cehennemden meded

105. Bahş ḳ1l ol ümmetime cenneti Yā ilāhỉ bin bir ismin hürmeti

106. Dilerseñ nār-1 cehennemden necāt Söyle her dem raşkile gel eṣ-ṣalāt

107. Ey Muhammed ümmeti sen ḳıl naẓar Kendiñe gel eyle Allāhdan ḥazer

108. Ṭ̂fl iken ol Habibullāh neyledi Günāhkār ümmetin Hakdan diledi 
109. Ümmet iseñ ol Resūle insāf et

Gel ayrılma izinden Hak yola git

110. Yarın görme huuzūūunda hacālet

Ümmetiyçün diler Haḳdan mağfiret

111. Tutar iseñ sen de anıñ sünnetin Şübhesiz bıraḳmaz elden ümmetin

112. Mekke ḳavmi eyler idi çün țavāf Cān-1 dilden diñle yok bunda hilāf

113. Kacbe şöyle secdelere ḳapandı Görenler hep Ka'be yıḳıldı șandı

114. Selām verdi Kacbe ol dem imāma Dīvārları kalḳ̣ı gine ḳıāma

115. Resūlüñ öñünde ḳoydu ol baş1 Ḥikmet-i Ḥaḳk oynamadı bir țaşı

116. Yaşı ḳırḳ deyince ol kān-1 rạ̣met Kondu hem başına tāc-1 nübüvvet

118. İndi Kuruān şān-1 pākinde anıñ Vaṣfın etmiş Ḥaḳk ol şāh-1 cihānı̃

120. Anıñ cism-i pāki idi șāfĩ nūr Oldu nice muccizāt andan zuhūr

121. Bir buluțu hāāim etdi Haḳk aña Nere gitse hem-rāh olurdu aña

122. Başı üstünde olurdu sāye-bān Anı̃̃ ile ol da olurdu revān

123. İki şāḳk etdi semāda ḳameri Dikdi ḳuru hūrma verdi șemeri

124. Cemālin seyr eden kāfir muhaḳḳak Nūr-1 ỉmānıla tolardı muṭlak

125. Dest-i pākinde idi Ḥaḳ fermānı Seyf-i mưcizātla açdı cihānı

126. Gölgesi düşmez idi aṣlā yere Nūra gark eylerdi varsa her nere

127. Dişlerinin żiyāsı düşse gece Görünürdü ḳaranlıḳda ḳarınca

128. Düssse yere gül biterdi terleri Misk [ü] canberle bezerdi yerleri

129. Dü cihānda verme bize mihnneti

130. Budur her dem 'ạṣi kullar niyāzı Mahșer günü sancaġına al bizi

131. Susuz koyma ḳyāmetde ümmeti Havż-1 Kevsserden içir sen şerbeti

132. Rabbenā ḳıl mağfiret ciṣyānımız İndiñde var çoḳ bizim nokṣānımız
133. Kullarıñ etse ḳapıñda āh u zār Baġışlamaḳ olur şān-1 Kirdgār

134. On sekiz biñ cālemin sulțānısıñ Her günāhkāra mürüvvet kānısıñ

135. Koyma bī-kes kıyāmetde kulları Saña maclūm müznibātı̃̃ hālleri

136. Ḥālim carż etmeğe yoḳdur liyāḳat Ṣırāt üstünden geçirsen selāmet

137. Mag̉firet ḳ̂l bu günāhkār ümmeti Enbiyā vü evliyānıñ ḥürmeti

138. $\quad$ Āl-i pāk-i Muștafāya bag̉ışla Sulțānım şānıña düşeni işle

139. 'Alī Bāḳī el açar iḥsānıña Pādişāhım bag̉lıyım fermānıña

140. Günāhım çok çünkü bir rū-siyāhım Senden başḳa yoḳ benim hiç penāhım

141. Dilerseñ nār-1 cehennemden necāt Söyle her dem caşkile gel eș-ṣalāt

Ek 2. Ali Bakî'nin Yeni Tulû'ât-ı Mevlûdü'n-Nebî Adlı Eseri

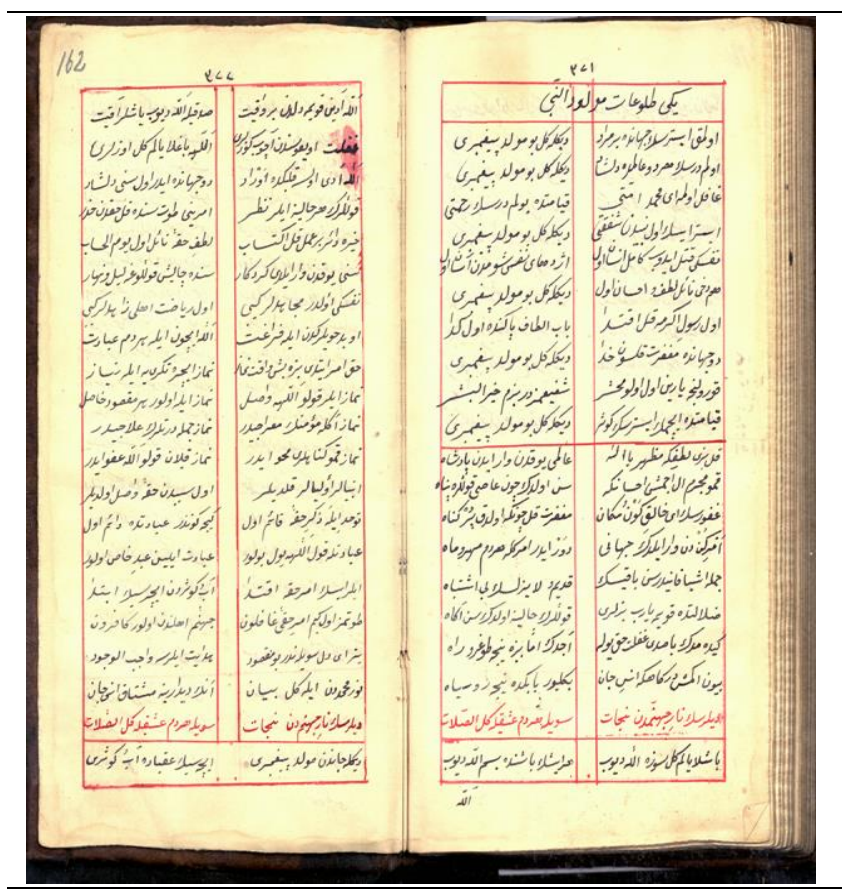

Arşiv: Ankara Milli Kütüphanesi, 06 Mil Yz A 5300 